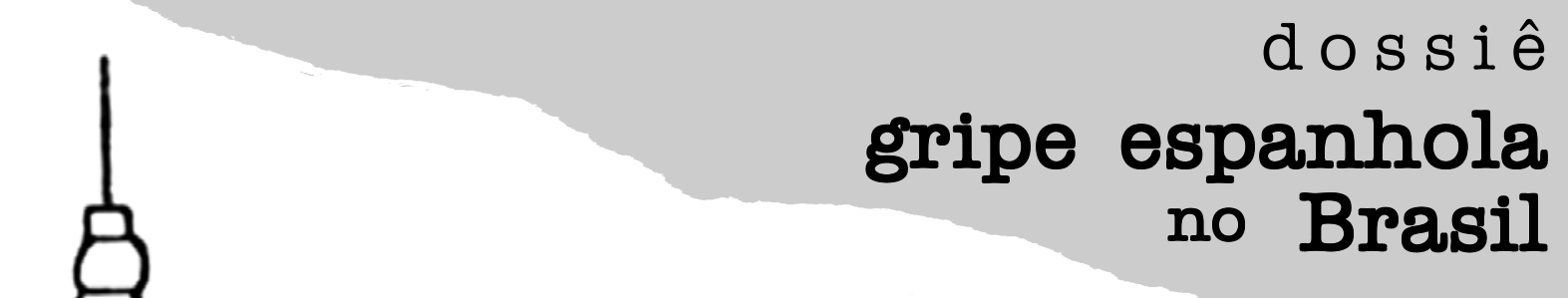

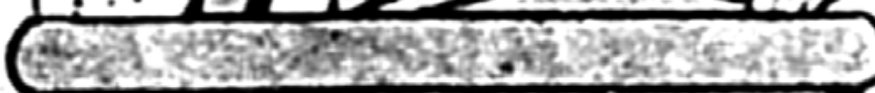

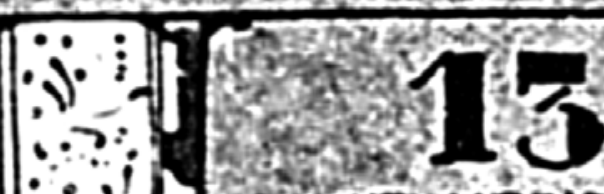

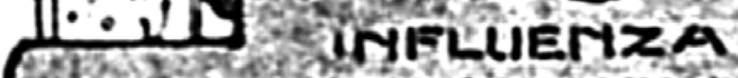

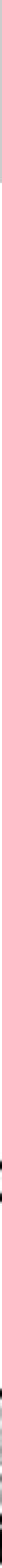

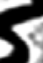

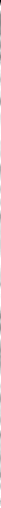



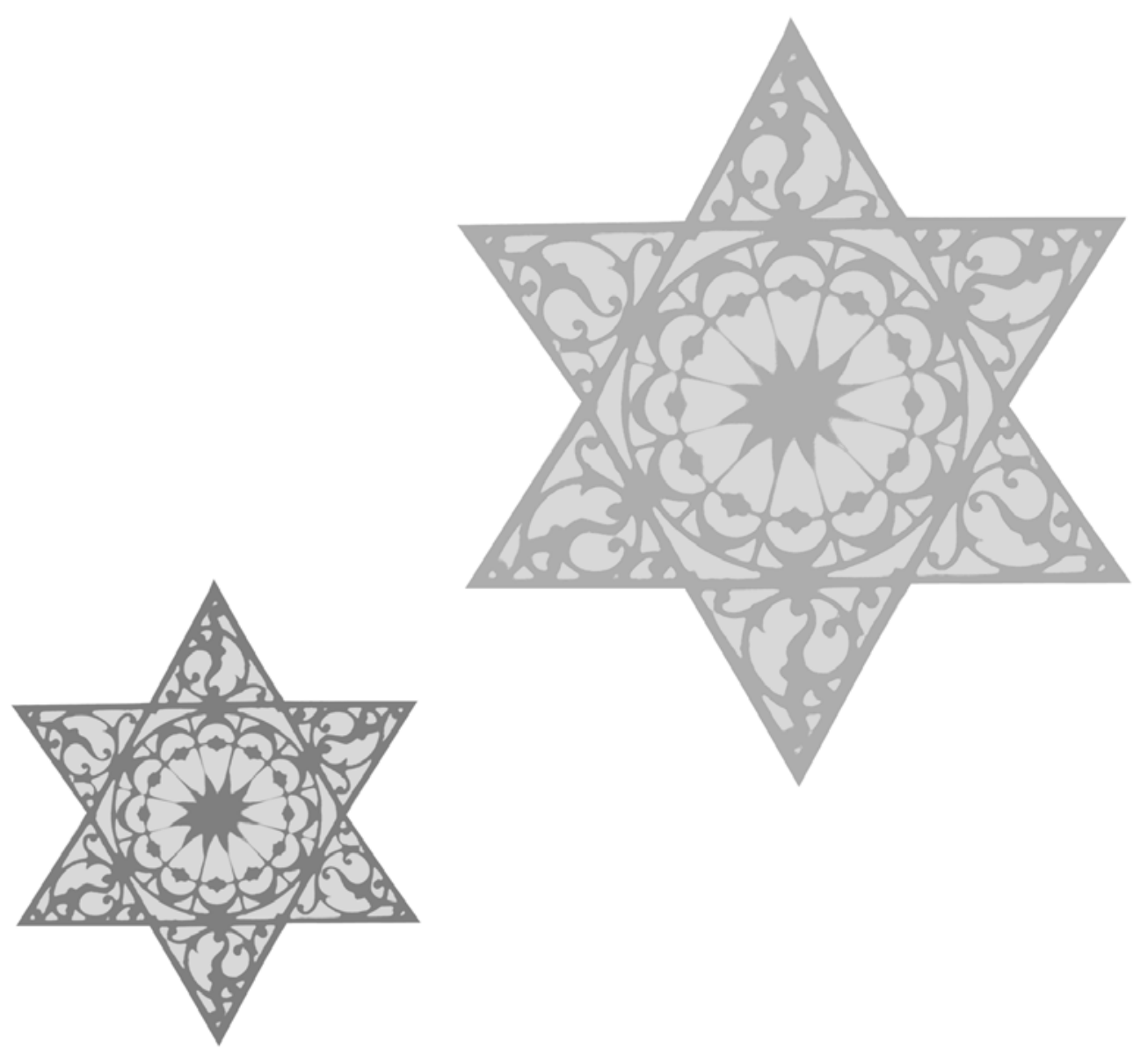


\section{A gripe espanhola em Salvador, 1918: cidade de becos e cortiços}

\section{The Spanish flu in Salvador, 1918: city of alleys and tenements}

SOUZA, C. M. C. de: A gripe espanhola em Salvador, 1918: cidade de becos e cortiços. História, Ciências, Saúde - Manguinhos, v. 12, n. 1, p. 71-99, jan.-abr. 2005.

Este artigo tem como objetivo investigar o episódio da epidemia de gripe espanhola que atingiu a cidade de Salvador e outras áreas da Bahia, tendo seu ápice entre setembro e dezembro de 1918. Utilizando como fonte privilegiada a imprensa local, analiso o jogo do poder, a condição sanitária da capital, alguns aspectos da economia, as condições materiais de sobrevivência dos moradores de Salvador, a fragilidade das políticas de saúde e assistência pública e outros aspectos de uma sociedade complexa e desigual evidenciados pela epidemia.

PALAVRAS-CHAVE: gripe espanhola, epidemias, política, Bahia.

SOUZA, C. M. C. de: The Spanish flu in Salvador, 1918: city of alleys and tenements. História, Ciências, Saúde - Manguinhos, v. 12, n. 1, p. 71-99, Jan.-Apr. 2005.

The article investigates the Spanish flu epidemic that hit the city of Salvador and the state of Bahia, reaching its height between September and December of 1918. The local press is a primary source in this analysis of power politics, sanitary conditions in the state capital, some economic issues, the material conditions for survival in Salvador, and the fragility of public health and assistance policies - all features of a complex, unequal society made visible by the epidemic.

KEYWORDS: Spanish flu, epidemics, policy,

Bahia.

Christiane Maria Cruz de Souza

Professora do Centro Federal de Educação Tecnológica da Bahia

Estrada Leopoldo Froés, 395/303

24360-005 Niterói - RJ Brasil

christianecruz@hotmail.com 


\section{Introdução}

E m agosto de 1918, em meio à movimentação das tropas envolvidas no conflito bélico que envolvia várias partes do mundo - a Primeira Guerra Mundial - irrompeu uma epidemia de influenza que, entre agosto e dezembro daquele ano, vitimou milhares de pessoas em todos os continentes.

Inicialmente o Brasil acompanhava a tragédia a distância, por meio das publicações dos periódicos de circulação diária nos diversos estados da federação, que relatavam a trajetória da epidemia na Europa. Contudo, na primeira quinzena de setembro de 1918, os brasileiros que participavam das operações de guerra, integrantes de missões médico-militares, após atracarem em Freetown, em Serra Leoa, e em Dacar, no Senegal, foram acometidos pela gripe que assolava esses portos africanos.

Não demorou muito para que a 'espanhola' chegasse ao país. Em 14 de setembro, o agente causador da moléstia aportava no Brasil a bordo do paquete inglês Demerara, que havia tocado os portos de Recife, Salvador e Rio de Janeiro (Bertolli Filho, 2003; Bertucci, 2004; Brito, 1997; Goulart, 2003). Como um rastilho de pólvora, a gripe se espalhava pelo país, e "a Bahia teve, naturalmente, de pagar o seu tributo à tremenda pandemia (...) que por toda a parte manifestou intensidade e expansibilidade nunca vistas" (Aragão, 1919, p. 51).

Em 24 de setembro de 1918, uma matéria publicada na primeira página do jornal $A$ Tarde informava que cerca de setecentas pessoas haviam contraído a moléstia em Salvador ( $A$ Tarde, 24.9.1918, p. 1).

No transcorrer daquele surto epidêmico, a imprensa local apresentou ao seu público leitor um arsenal de informações sobre a epidemia que assolava Salvador. Estabeleceu-se nos jornais um debate acerca das condições sanitárias do estado, do número de pessoas infectadas e/ou vítimas da influenza, da etiologia da doença, das medidas tomadas pelas autoridades para conter a disseminação da moléstia etc.

O discurso tecido em torno da epidemia, veiculado nos periódicos de circulação diária em Salvador, pode revelar diferentes aspectos da sociedade da capital baiana: as mediações efetuadas no plano do estado, o conhecimento médico, as políticas de saúde pública, as exigências do sistema econômico, as percepções e representações das doenças e as respostas das pessoas comuns.

Partindo do princípio de que a doença é um problema que tem uma dimensão biológica, mas também está carregado de conotações sociais, culturais, políticas e econômicas, discutiremos aqui a epidemia de gripe que atingiu Salvador entre setembro e dezembro de 1918 como um fato social capaz de acirrar a disputa política, inter- 
romper as atividades produtivas e mobilizar variados setores daquela sociedade.

Na primeira parte deste trabalho, analisaremos o cenário político e social baiano. Na segunda, revelaremos, de forma breve, como a penetração e os efeitos do flagelo foram explicados pelo discurso das autoridades médicas e sanitárias, e quais as medidas tomadas para conter o surto epidêmico que se desenrolava em tal contexto político-social. Para tanto, utilizaremos como fontes privilegiadas os jornais que circulavam na capital da Bahia no período de erupção da 'espanhola'.

No período estudado, havia em circulação na Bahia um grande número de jornais - Diário de Notícias, Diário da Bahia, Jornal de Notícias, A Tarde, Jornal Moderno, O Democrata, A Cidade, O Imparcial, A Hora e Diário Oficial - , e raras eram as cidades ou vilas do interior que não possuíssem seus órgãos de imprensa (Aragão, 1918). Contudo, tais órgãos eram criados, atuavam e morriam conforme os interesses das facções reinantes no cenário político baiano (Sampaio, 1999). Portanto, no exercício das suas funções, eles não omitiam suas vinculações político-partidárias. Muitos deles se aproveitavam dos períodos de crise desencadeados por epidemias para desacreditar o grupo que assumia poder no estado naquele momento.

Para a realização deste trabalho, elegemos como fontes o Diário da Bahia, O Democrata, o Diário de Notícias e A Tarde, visto que tais periódicos revelavam diferentes facetas da realidade estudada, expressando a opinião das diversas facções que dominavam o cenário político baiano.

O Diário da Bahia pertencia, no período, aos herdeiros do exgovernador Severino Vieira, franco opositor do grupo político liderado por José Joaquim Seabra, que exercia o poder na Bahia. Já o jornal $O$ Democrata era um órgão de imprensa claramente vinculado à situação, e cuidava de veicular as notícias favoráveis ao governo do grupo 'seabrista'. Por sua vez, o jornal $A$ Tarde, de propriedade de Ernesto Simões Filho, exercia livremente a oposição ao grupo governista. Dentre esses periódicos, visivelmente vinculados às diferentes facções políticas, o Diário de Notícias pretendia manter uma posição de neutralidade no cenário político baiano.

Salientamos que, além dos mencionados periódicos, foram tomados como fontes a documentação produzida no governo de Antonio Muniz Ferrão de Aragão, arrolada no Arquivo Público do Estado da Bahia, as memórias históricas e/ou publicações científicas arquivadas na Faculdade de Medicina da Bahia ou veiculadas pela Gazeta Médica da Bahia, bem como registros arquivados na Santa Casa de Misericórdia. Partindo desses dados, abordaremos a seguir o episódio da epidemia de gripe espanhola que assolou a capital baiana no ano de 1918 . 


\section{Salvador em 1918: política e sociedade}

Quando a gripe espanhola aportou na Bahia, ali reinava um clima de insatisfação, conflito e insegurança gerado por determinados fatores: as disputas de poder entre as diversas facções políticas; a crise financeira do estado; a carestia e a pobreza generalizada; as greves; as transformações urbanas que desalojaram grupos sociais inteiros, sem, no entanto, dotar a cidade de uma estrutura sanitária satisfatória.

As condições de sobrevivência material da maioria da população de Salvador eram consideradas as piores possíveis. Os relatórios apresentados à Diretoria Geral de Saúde Pública por seus inspetores sanitários denunciavam a vida miserável do povo (Secretaria do Interior e Justiça, Diretoria Geral de Saúde Pública, Relatórios de 18 Distritos Sanitários, 1912-1924). As camadas menos privilegiadas da população trabalhavam em excesso e eram pessimamente remuneradas, o que resultava em esgotamento físico e privações como a má alimentação, a moradia em habitações insalubres, mal arejadas, úmidas e escuras - onde as pessoas se aglomeravam em compartimentos de capacidade insuficiente -, situadas em becos e ruelas que careciam de limpeza e pavimentação, além de um serviço regular de água e esgoto (id. ibid.).

O inspetor sanitário do $9^{\mathrm{o}}$ Distrito, dr. Álvaro da Franca Rocha, no seu relatório semestral apresentado à Diretoria Geral de Saúde Pública, afirmava que a miséria era uma porta aberta à infecção, tendo em vista que o organismo enfraquecido não the poderia fazer resistência. Para reverter esse quadro, seria necessário tirar o povo da condição miserável em que vivia, "entregue aos vícios, ao alcoolismo, mal alimentado, habitando verdadeiros antros, sem ar e sem luz" (DGSP, Inspetoria do 9o distrito, Bahia, 1913).

Por sua vez, em épocas diferentes, nos relatórios apresentados à mesma repartição, o dr. Aristides Novis e o seu sucessor no posto de inspetor sanitário do $5^{\mathrm{o}}$ distrito, o dr. Collatino de Borborema, registraram a falta de esgotos em vários pontos da cidade. Novis (id. ibid.) se horrorizava com o "sistema deplorável [de] fossas fixas, muitas das quais expostas", e com os "antros abjetos, onde a umidade, a treva e o calor abriga[vam] com a população pobre da Bahia, os agentes da sua destruição".

Em 1920, de acordo com o relatório apresentado pelo dr. Candido Figueiredo (id. ibid.), inspetor sanitário do $17^{\circ}$ distrito, a situação não havia se modificado. O 17º distrito abrangia a "vasta circunscrição sanitária que constitui[a] a zona fabril". No relatório, o dr. Figueiredo lamentava que as fábricas não edificassem vilas operárias, com moradias simples, mas dentro das normas higiênicas, para abrigar o grande número de trabalhadores que ali se concentrava, 
${ }^{1}$ Os professores entraram em greve no dia 12 de março de 1918 (Tavares, 2001, p. 335), e os operários paralisaram suas atividades no dia 23 de setembro do mesmo ano (A Tarde, 24.9.1918, p. 1).
2 Segundo Sampaio (1999), nas primeiras décadas do século XX, $82 \%$ da população baiana não sabiam nem ler nem escrever; e como, no novo regime republicano (assim também no monárquico), o analfabeto não podia votar, quase toda a população baiana estava impedida de participar da vida política do estado e do país. residindo em prédios condenados por aquela inspetoria, situados "em pontos reconhecidamente insalubres" (id. ibid.).

Além disso, os soteropolitanos conviviam com o alto preço dos gêneros de primeira necessidade. A carestia que imperava em Salvador levou um jornalista de $A$ Tarde $(13.9 .1918$, p. 1) a clamar: "Apiedai-vos do povo, já na iminência da fome! Pão, bacalhau, charque e açúcar. Urge baixar-lhes os preços proibitivos para a pobreza. A crise alimentícia torna-se intolerável". Esse estado de coisas era tão preocupante que comerciantes, representantes do poder público e membros da diretoria do Centro Operário se reuniram na Intendência Municipal para tentar resolver o problema $(A$ Tarde, 14.9.1918, p. 1). O objetivo do encontro era estabelecer a conciliação entre as tabelas de preço do comércio atacadista e varejista, no intuito de oferecer algum alívio à população. Entretanto, apesar da tentativa de acordo e de redução de preços, a carestia continuou a oprimir o orçamento do povo baiano, 'justificada' pela carga tributária imposta ao comércio do estado.

No decorrer do ano de 1918, em meio a um contexto de crise nas finanças públicas e de carestia, professores e um grupo de operários da Fábrica Conceição, de propriedade da União Fabril, entraram em greve, reivindicando o pagamento de salários atrasados (no caso dos professores) e aumento salarial (no caso dos operários). ${ }^{1}$ Sobre a greve dos operários, uma notícia publicada no jornal $A$ Tarde informava que a reivindicação de aumento nos salários se devia à "alta clamorosa dos gêneros de primeira necessidade" (24.9.1918).

Todavia, ainda que estes trabalhadores se mobilizassem para resolver problemas como a iminência da fome e salários não pagos, não podemos afirmar que na Salvador da República Velha existisse a inserção de um partido organizado pelos trabalhadores no quadro político baiano (Sampaio, 1999). Além do mais, a repressão exercida pelas elites e o analfabetismo da maioria do povo baiano inibiam qualquer iniciativa de participação popular naquele cenário político. ${ }^{2}$

Assim, pode-se afirmar que a passagem da Monarquia para a República pouco alterou a configuração política do estado da Bahia. As camadas populares estavam excluídas do processo político-partidário, e a elite política baiana, que num primeiro momento repudiou a mudança do sistema político, por fim acabou aderindo a ele, amoldando-se às suas instituições e fazendo com que estas se ajustassem aos seus tradicionais padrões de comportamento.

Até a primeira década do século XX, sob a égide da República, líderes políticos como Luiz Vianna, Severino Vieira e José Marcelino - monarquistas conservadores - continuaram a conduzir a política partidária do estado. Nesse período, o panorama político era dominado pelo personalismo dos coronéis e por uma ainda 
${ }^{3}$ De acordo com

Pang (1979), o coronelismo baiano já se firmara nos moldes de uma oligarquia familiocrática. A dificuldade de comunicação e transporte favoreceu o insulamento do interior em relação à capital ou às cidades costeiras do estado, fazendo com que cada área de produção agrícola ou de mineração assumisse características semi-autônomas. Cada centro econômico e espacial era um núcleo oligárquico cujo poder era reforçado por laços familiares e de negócios estabelecidos com membros da elite política do interior de outros estados.

4 Para Sampaio (1999, p. 79), esses elementos representativos da sociedade eram na verdade "o pequeno grande mundo agrocomercial" do estado.

\footnotetext{
5 Seabra assumiu o cargo de governador do estado da Bahia em março de 1912, após um tumultuado processo eleitoral que culminou com o bombardeio de Salvador. Para saber mais, consultar Pang (1979, p. 89-112).

6 Segundo Seabra, restava apenas o senador Luiz Vianna, que, tendo pertencido a mesma facção, passara a lhe fazer oposição. Entretanto, a morte do exgovernador Severino Vieira não enfraqueceu a oposição aos 'seabristas'. Ainda que seu partido tivesse desaparecido, o 'severinismo' se manteve ativo na pessoa de Pedro Lago.
}

incipiente organização partidária. ${ }^{3}$ Coexistiam na Bahia cerca de 13 partidos, ao sabor dos interesses pessoais daqueles que não queriam estar apartados do poder (id. ibid.).

O primeiro passo para a criação de um partido político em torno do qual se procuraria congregar os 'elementos representativos da sociedade' foi a fundação, em 1901, do Partido Republicano da Bahia - PRB. ${ }^{4}$ O partido esteve em atividade até 1911 , representando os interesses da burguesia agrocomercial e agregando, sob a mesma égide, conservadores, liberais, federalistas e constitucionalistas.

No entanto, a campanha para sucessão presidencial, em 1910, dividiu a Bahia entre partidários de Ruy Barbosa e Albuquerque Lins, 'civilistas', e partidários de Hermes da Fonseca e Wenceslau Brás, 'hermistas'. A vitória de Hermes da Fonseca resultou no enfraquecimento do PRB, cujos integrantes haviam apoiado a candidatura Ruy/Albuquerque. Além do mais, o governo Hermes tinha interesse em enfraquecer o poder das oligarquias tradicionais. Assim, em 1910, surgiu a necessidade de se criar na Bahia um partido ligado a essa nova feição do poder republicano.

Por ele ter liderado a campanha em prol de Hermes da Fonseca e ocupado o cargo de ministro da Justiça e Negócios Exteriores no governo Rodrigues Alves, recaiu sobre J. J. Seabra a incumbência de fundar o Partido Republicano Democrata (PRD), juntamente com elementos da nova geração de políticos anteriormente agrupados em torno da campanha 'hermista'. A partir de então, por um período de 12 anos (de 1912 até 1924), o PRD, sob o comando de Seabra, assumiu um papel de liderança na política da Bahia.

Seabra articulou cuidadosamente esse papel convergente do PRD. Após ter sido eleito governador, implementou a Lei da Reforma, de 11 de agosto de 1915, que dava direito ao governante estadual de nomear os intendentes municipais. ${ }^{5}$ Assim, estabeleceu-se uma dependência dos intendentes em relação ao governador, que procurou também centralizar as ações assistencialistas e a seleção dos funcionários públicos dos municípios. Deste modo, nas duas últimas décadas da República Velha, poucos eram os políticos da Bahia que não rezavam pela cartilha 'seabrista'.

Em 1918, em discurso pronunciado no Senado, Seabra afirmaria que as oposições, na Bahia, tinham sido aniquiladas desde a morte de seus principais líderes - José Marcelino e Severino Vieira (Seabra, 1918, p. 18). ${ }^{6}$ Segundo ele, o Partido Democrata "se desenvolveu, prosperou e venceu", mesmo à revelia do senador Ruy Barbosa. O PRD era, na visão daquele político, o único partido da Bahia que poderia ser considerado "forte, organizado, coeso" (id. ibid.). Tal coesão política era importante para o restabelecimento da autoridade do estado, fortemente abalada pelo sistema coronelista vigente, que estorvava a execução de leis e políticas públicas. 
A existência de um partido forte, cujo líder ocupara o cargo de governador do estado, não modificara radicalmente a estrutura político-social da Bahia durante a República Velha. Nas primeiras décadas do século $X X$, a ausência da administração pública em áreas fundamentais como a saúde fortalecia o poder local por meio da distribuição de favores à população pelos 'coronéis' ou correlatos.

Além disso, na Bahia da Primeira República, a organização e reorganização do serviço público, medida recorrente toda vez que uma nova facção política assumia o governo, constituíam um entrave para seu bom funcionamento. Ao ascender ao cargo de governador, os políticos, além de mudarem as leis, colocavam seus apaniguados nos postos públicos; ocorria que, na maioria das vezes, tais indivíduos não tinham qualquer formação acadêmica ou experiência para ocupar essa função.

A política de distribuição de favores e de postos em repartições públicas recrudesceu no governo de Antonio Moniz (1916-1920). Apadrinhado de Seabra, Antonio Ferrão Moniz de Aragão tomou posse, em abril de 1916, para um mandato de quatro anos como governador do estado. Incomodado com a posição de preposto daquele líder político, e ansioso por estruturar uma máquina administrativa própria, este governador procurou controlar mais estreitamente a política municipal, reduzindo o mandato dos intendentes de quatro para dois anos. Com o mesmo intuito e com mais liberalidade ainda que Seabra, distribuiu favores políticos, incorrendo inclusive na prática do nepotismo. Esta postura era criticada e denunciada pela oposição. A respeito disso, em matéria publicada no Diário da Bahia, a facção 'severinista' assim se pronunciava:

O assunto que, hoje, nos detém é o importante problema da saúde pública, em favor do qual o sr. Moniz não destina algumas horas de lazer.

Sabemos que suas preocupações são múltiplas.

Enquanto houver um parente em condições de merecer o auxílio dos cofres, o governador não tem tempo de curar de outros misteres, de menor importância no seu modo de entender (Diário da Bahia, 6.10.1918, p. 1).

O nepotismo e o clientelismo perpassaram todas as instâncias administrativas do estado, afetando diretamente as finanças públicas. A situação de penúria financeira que a Bahia atravessava naquele período era em grande parte resultante da política de concessão de favores em vigor.

No sistema financeiro do estado, as coletorias fiscais eram peças-chave no sentido de evitar a evasão de impostos interestaduais. Nesse contexto, o coletor de impostos assumia um papel de desta- 
7 Uma intervenção federal afetaria o principio da autonomia, próprio do sistema federa-lista, estabelecido pelo artigo $\mathrm{n}^{\mathrm{O}} 50 \mathrm{da}$ Constituição de 1891. As epidemias eram comu-mente utilizadas pela imprensa de oposição para conseguir a intervenção federal, desacreditando, assim, os representantes de determinada facção política que se encontrava no poder. que, na medida em que era responsável pelo serviço de arrecadação do estado. O posto de coletor, assim como a maioria dos cargos públicos estaduais, era alvo de disputas e barganhas no cenário político. Nessas circunstâncias, o coletor estava sempre ligado a uma facção política que dominava uma determinada região. Essa vinculação político-partidária era prejudicial ao erário, tendo em vista que o pagamento de impostos era tido não como uma obrigação cívica, mas como uma punição aplicada aos inimigos políticos.

Assim, as rendas do estado, baseadas na arrecadação de impostos sobre a exportação de mercadorias para o estrangeiro ou para dentro do país, sobre bens imóveis urbanos e rurais, sobre transmissão de propriedades e sobre indústrias e profissões, ficavam seriamente prejudicadas (Bahia, Secretaria da Fazenda, 1985, p. 15). O imposto territorial, que era uma importante fonte de receita nos grandes estados da federação desde o início da República, não pôde ser implantado na Bahia em razão da grande oposição por parte das oligarquias agrárias.

Para agravar o quadro de desequilíbrio orçamentário do estado, as rendas obtidas com o comércio de exportação eram afetadas pela dependência estrutural que esse tipo de atividade tinha em relação a firmas e capitais estrangeiros (Sampaio, 1999). Uma parte considerável do "excedente gerado pela exportação era transferido para a Europa, através de importações, de remessas de lucros, pagamentos de juros e amortizações da dívida externa" (id. ibid., p. 35 ). A situação fica mais visível quando examinamos, por exemplo, o ano de 1917: nesse período, enquanto a exportação compreendeu $50 \%$ da receita ordinária, as rendas das coletorias atingiram pouco mais de 12\% (Bahia, Secretaria da Fazenda, 1985, p.16).

Assim, o estado se via sem recursos financeiros para executar ou consolidar políticas públicas. Enquanto as ações em prol da saúde coletiva sofriam os efeitos de uma economia dependente do capital estrangeiro e da ingerência do erário público, por sua vez a economia era afetada pelo precário estado sanitário da capital.

Quando a febre amarela irrompeu em Salvador, o jornal A Tarde trazia em sua primeira página uma reportagem sobre o grande número de casos registrados e aventava a probabilidade de intervenção da União na Bahia, tendo em vista que "o Tesouro só" não poderia "comportar as despesas de uma larga, completa profilaxia, do ataque radical violento à epidemia" ( $A$ Tarde, 24.5.1918, p. 1). ${ }^{7}$ A matéria em questão versava também sobre os riscos e implicações da erupção de uma epidemia sobre as atividades econômicas do estado. Surtos epidêmicos como este eram prejudiciais à economia baiana, baseada na exportação de produtos como café, tabaco, cacau, açúcar e algodão - e dependente do mercado externo. Era, portanto, preocupante saber que "diversos estrangeiros, com importantes negócios no estado", ficaram 
${ }^{8}$ Durante a Primeira Guerra Mundial, a Inglaterra impôs restrições ao comércio do Brasil com a Áustria e a Alemanha - navios com carregamento de produtos brasileiros eram apreendidos pela Marinha britânica, prejudicando diretamente o comércio de exportação da Bahia (Pang, 1979).

\footnotetext{
${ }^{9}$ No primeiro governo de J. J. Seabra (1912-1916) teve início a reforma urbana de Salvador, fato comum na época a outras capitais brasileiras (Castro Santos, 1998; Benchimol, 1992; Pinheiro, 2002). A nova proposta urbanística de Salvador visava a higienização e o saneamento da cidade, eliminando quarteirões insalubres repletos de velhos sobrados, becos escuros e fétidos, calçadas repletas de ambulantes e seus tabuleiros. A abertura de novas avenidas, assim como a reconstrução das fachadas arquit
}

"visivelmente alarmados" com a possibilidade da erupção de uma epidemia (id. ibid., p. 1).

Além disso, se a guerra já havia diminuído a freqüência de navios mercantes no porto de Salvador, criando sérias dificuldades para a circulação de mercadorias e de passageiros, pior seria a situação em caso de epidemia. ${ }^{8}$ De acordo com o mesmo artigo do jornal $A$ Tarde, a situação poderia se agravar até o ponto de "calamidade pública", e a Bahia ficaria "seqüestrada do resto do mundo, de todo o Brasil", se não fossem "postas em prática medidas urgentíssimas de saneamento" (id. ibid.).

Nessas circunstâncias, era preciso preservar a cidade, local por excelência das transações comerciais, pois qualquer ameaça aos negócios repercutiria nos setores dominantes da sociedade baiana. Portanto, cabia ao governo prover um porto 'limpo' aos negociantes, combatendo as doenças que alarmavam ou espantavam os importadores, tendo em vista que os navios de algumas empresas, como atestava a imprensa local, poderiam se recusar a atracar no porto de Salvador por considerá-lo 'sujo'.

Entretanto, apesar da reforma urbana empreendida no primeiro governo Seabra, no intuito de ordenar e purificar o espaço público, inclusive o portuário, o estado sanitário de Salvador não era dos melhores. ${ }^{9}$ Para Ruy Barbosa, representante da Bahia no Senado, Salvador, cidade de quase trezentos mil habitantes, encontrava-se em estado lastimável - sem água, luz, escolas e sem pagar ao professorado (Seabra, 1918). De acordo com um artigo publicado no Diário da Bahia (6.10.1918), não havia higiene em Salvador. Para o grupo que dirigia este jornal de oposição, o asfalto que revestia algumas das propaladas avenidas abertas por J. J. Seabra escondiam e mal disfarçavam "aos olhos ingênuos, a miséria, a imundície reinante" (id. ibid., p. 1). Essa opinião era endossada por artigos publicados em outros periódicos que circulavam na cidade em 1918; um dentre eles relatava também que, em Salvador, "cidade de becos e cortiços", não havia uma preocupação com a higiene nem das ruas nem das casas, "em muitas das quais os seus proprietários não [faziam] a menor pintura ou o mais ligeiro reparo" (Diário de Notícias, 18.10.1918, p. 1).

O dr. Collatino de Borborema, inspetor sanitário do $5^{\circ}$ distrito, traçava um quadro semelhante àquele que aparecia nos jornais. Em relatório semestral dirigido à Diretoria Geral de Saúde Pública, solicitava que o diretor interviesse junto ao poder municipal no sentido de sanar uma série de problemas detectados naquele distrito, tais como a falta de redes de esgotos, de canalização de água, de calçamento e a vegetação crescente em muitas ruas (Relatório apresentado à Diretoria Geral de Saúde Pública, Inspetoria do 5을 Distrito, Bahia, 10.6.1918). 
10 Entende-se por inter-dependência a ligação de recíproca dependência que se estabelece entre a elite e os pobres, em virtude da qual ocorre o auxílio mútuo ou a coadjuvação recíproca.
Assim, podemos inferir que, apesar da reforma urbana iniciada em 1912, o estado de insalubridade da cidade do Salvador era um problema que ainda não tinha sido solucionado. Era crescente, nesse período, a participação de alguns setores da sociedade - intelectuais e políticos egressos da classe média e das novas profissões emergentes - na defesa de melhores condições de vida e de trabalho para as populações urbanas e rurais do país (Castro Santos e Faria, 2003; Hochman, 1998; Hochman e Lima, 1998).

O debate em torno de tais questões tomou impulso a partir da divulgação dos relatórios das expedições científicas organizadas pelo Instituto Oswaldo Cruz, em 1912, que, ao percorrerem a região compreendida entre o sul do Pará, todo o território goiano, o sudoeste de Pernambuco e o norte da Bahia, diagnosticaram a situação de doença e abandono em que se encontrava a população do interior do país (id. ibid.).

A partir deste reencontro com os 'sertões', as ações em saúde pública passaram a representar uma via para conformação da identidade nacional. Assim, 'nacionalistas de diversos matizes' passaram a considerar o saneamento das áreas urbanas e rurais como um fator primordial para o progresso do país (Castro Santos e Faria, 2003, p. 29). Tal dimensão da nacionalidade foi encampada por parte da elite, cada vez mais consciente do processo de interdependência sanitária e territorial (Hochman, 1998; Swaan, 1988 , p. 1-142). Essa percepção de interdependência ${ }^{10}$ se intensificou à medida que se compreendia que as epidemias afetavam ricos e pobres indistintamente, e que as endemias eram um fator de entrave ao desenvolvimento econômico do país. A consciência dessa interdependência entre elites e pobres é central ao processo coletivizador que se iniciava no Brasil da Primeira República.

O movimento em prol do saneamento do Brasil era amplamente divulgado pelos meios de comunicação da época, e o ideário sanitarista aos poucos foi se incorporando ao consciente coletivo. Em Salvador, os órgãos de imprensa de oposição se apropriaram desse discurso para denunciar o precário estado sanitário da Bahia, sem, no entanto, questionar as condições de pobreza a que estava submetida a maior parte da população baiana. Pode-se compreender melhor como isso acontecia ao examinar a seguinte matéria jornalística sobre o impaludismo veiculada pela imprensa baiana:

O impaludismo lavra e o governo é indiferente.

É uma reclamação de todos os dias.

Desde os arrabaldes da Capital, o recôncavo, o litoral e o interior, até a zona opulenta do sul - o clamor é uníssono contra os estragos do impaludismo! 
Ora, são as próprias vítimas, abatidas pela endemia maldita, ora são homens de consciência e coração, revoltados pelo sofrimento de seus semelhantes que vêm à $A$ Tarde rogar que ela brade alto contra a incúria e criminosa indiferença que o governo assiste, impassível, a inutilização e extermínio da população rural do Estado.

(...)

$\mathrm{Na}$ dificuldade em que nos achamos para levar avante o momentoso problema do saneamento da Bahia, lembramos que desde já, se poderia fazer alguma cousa no tocante ao impaludismo: a vendagem do quinino a preços módicos, entrando nesse serviço a fiscalização do Estado, não só quanto aos preços elevados, como quanto às falsificações.

Não ignoram os que conhecem o interior, a impossibilidade em que se acham as populações pobres de obter o quinino.

(...)

Esses infelizes doentes, maltratados, são outras tantas sementeiras onde o mosquito vai colher e disseminar pelas pessoas sãs, inoculando-lhes no sangue, os germes do impaludismo ( $A$ Tarde, 8.5.1918, p. 1, grifos nossos).

A percepção de que indivíduos pobres e doentes poderiam se tornar 'sementeiras' de doenças, disseminando-as entre as 'pessoas sãs', foi um dos elementos propulsores do movimento sanitarista brasileiro. Além disso, a doença ameaçava a reserva de trabalhadores potenciais, recrutas, consumidores e partidários políticos, tornando-se por isso necessário à elite trabalhar em prol da harmonia e também da saúde pública, implementando políticas públicas.

Entretanto, na Bahia, além da politicagem, a falta de recursos técnicos e financeiros, tanto estaduais quanto municipais, dificultavam a implementação de políticas públicas de saúde. A chegada da gripe espanhola contribuiu para desnudar as fragilidades do serviço de saúde pública, já que agravou as condições sanitárias do estado. A epidemia de gripe tornou-se então um instrumento das diversas facções políticas que se digladiavam pelo controle do poder. Os jornais eram os veículos dessa disputa, como se pode observar a seguir.

\section{A 'espanhola' aporta em Salvador}

É difícil precisar o momento da entrada da 'espanhola' na Bahia. Para o governador do estado à época, a epidemia iniciou-se em 27 de setembro de 1918 (Aragão, 1919). Por sua vez, o jornal A Tarde informava que em 24 de setembro de 1918, "a epidemia desconhecida" já assolava a Bahia, tendo sido verificados "cerca de setecentos enfermos nos quartéis, nos hospitais em casas particulares e em todos os centros de aglomeração de operários" (A Tarde, 25.9.1918, p. 1). Con- 
$11 \mathrm{O}$ dr. Gonçalo Moniz (28.1.18701.6.1939) era considerado pelos seus pares um dos maiores expoentes da medicina baseada no conhecimento etiológico de suporte experimental. Ingressou como professor da Faculdade de Medicina em 1895 apresentando a tese de concurso intitulada $D a$ imunidade mórbida (estudo geral).

Inaugurou então uma carreira voltada para estudos no campo da microbio-logia. Em 1899 montou e dirigiu o Gabinete de Análises e Pesquisas Bacteriológicas da Bahia. Publicou vários estudos e

observações sobre a peste bubônica e a tuberculose. Gonçalo Moniz ocupou a Secretaria do Interior, Justiça e Instrução Pública em 1916, no governo de Antonio Ferrão Moniz de Aragão. tudo, se considerarmos o período de transmissibilidade da doença e o intervalo de tempo necessário para que os seus primeiros sinais se manifestassem, perceberemos que o mal já estava entre os baianos antes das datas assinaladas, ainda que não tenha sido registrado pelos órgãos de imprensa nem pela Diretoria Geral da Saúde da Bahia.

Na Bahia, embora as autoridades políticas, médicas e sanitárias acompanhassem, pelos jornais, a evolução simultânea da epidemia em vários lugares do mundo, elas pareciam considerar remota a possibilidade de que um mal que grassava em lugares tão distantes do Brasil pudesse vir a vitimar também o povo baiano. Mesmo quando os primeiros rumores da existência de uma epidemia de gripe em Salvador começaram a circular, ainda assim as autoridades não deram a devida importância - tratava-se apenas de uma enfermidade familiar à sociedade baiana que, até então, não tinha apresentado graves conseqüências. Portanto, em um primeiro momento, o governo baiano, assim como os governantes de outras partes do mundo, assumiu uma postura passiva, propalando a benignidade da doença.

Para a imprensa, a moléstia se espalhava com uma rapidez surpreendente, e, assim como a gripe, as críticas ao imobilismo das autoridades em face da epidemia reinante vinham 'a galope'. As matérias sobre o assunto continham um misto de indignação e ironia diante da paralisia que dominava a Diretoria de Saúde Pública da Bahia. Um artigo do jornal $A$ Tarde traduzia a perplexidade da população, ao afirmar que "ninguém" sabia "por que a direção interina da S.P.B. não cogita[va] do caso, não providenciando (...) o saneamento" e a "aplicação de medidas profiláticas". De acordo com a matéria, a postura do governador era de indiferença "diante da percentagem assombrosa de enfermos na capital" ( $A$ Tarde, 25.9.1918, p. 1)

As autoridades pareciam preferir negar o fato. Abordados pelos jornais do Rio de Janeiro, os políticos da situação, bem como as autoridades médicas, atribuíam à imprensa de oposição a responsabilidade pelo caráter alarmista que tomava a notícia de um simples surto de gripe. Solicitado a dar a sua opinião a um jornal da capital federal, o deputado Arlindo Leone, partidário de J. J. Seabra, afirmou que a epidemia de gripe não passava de uma invenção de oposicionistas sem escrúpulos que faziam de tudo para desmoralizar a Bahia (Diário de Notícias, 30.9.1918).

O secretário do Interior, Justiça e Instrução Pública do Estado da Bahia, dr. Gonçalo Moniz, ao ser entrevistado pelo jornal carioca $A R u a$, descartou qualquer possibilidade de haver epidemia de gripe na Bahia, argumentando que, caso tivesse ocorrido algo de anormal, ele teria sido imediatamente avisado pelas autoridades sanitárias. ${ }^{11}$ Portanto, não acreditava na "devastação anunciada" pela imprensa de oposição (A Tarde, 30.9.1918). 
12 Segundo o jornal A Tarde (27.5.1918, p. 1), o governo do estado declarou por decreto extinta a febre amarela na Bahia, atribuindo o feito ao dr. Gonçalo Moniz, que foi aclamado na Academia Nacional de Medicina por seu experimento com os vapores de creolina na eliminação do mosquito transmissor da moléstia. Com a recrudescência do mal, caiu por terra o 'embuste', e o governo federal, decepcionado com a dissimulação das autoridades da Bahia, tomou as devidas providências para evitar que a doença se alastrasse para outros portos do país (id. ibid.).
Essas declarações foram imediatamente divulgadas pelos órgãos da imprensa oposicionista baiana, que não pouparam Arlindo Leone nem Gonçalo Moniz de sua crítica mordaz. Em matéria de primeira página, o jornal $A$ Tarde (30.9.1918, p. 1) propalava que o dr. Gonçalo Moniz, ao afirmar que não havia uma epidemia de gripe em Salvador, perdera a compostura própria das suas "poses de sábio indígena", fazendo jus ao apelido de "mentira". ${ }^{12}$ Por sua vez, o Diário da Bahia (5.10.1918, p. 1) denominava-os de "próceres da mentira", acrescentando que estes que negavam a existência da moléstia em Salvador eram aqueles que viviam na capital da República, "parasitariamente, sugando, em pura perda, os cofres públicos".

Acusada de explorar os fatos para denegrir a imagem do Bahia, a facção política 'severinista' que dirigia o Diário reagiu contra-atacando. Publicou uma nota em que se justificava diante dos leitores, afirmando que, se colocava "a nu as chagas miseráveis da Bahia", era porque desejava promover "uma transformação absoluta dos costumes, das práticas usadas" naquele período pelo grupo que estava à frente do governo estadual (Diário da Bahia, 6.10.1918, p. 1).

Para a oposição, a Bahia era comandada por um "bando aventureiro", indiferente a qualquer outra coisa que não seus interesses pessoais, a ponto de ter arrastado o estado para o desastre financeiro e provocado o abandono de "vários ramos da administração pública". Para arrematar a composição do quadro desastroso do governo baiano, a referida matéria destacava o problema da saúde pública, "em favor do qual o sr. Moniz não destina[va] algumas horas de lazer". E ironizava: "Felizes de nós se pudéssemos, conscientemente, tecer louvores à ação governamental..." (id. ibid., p. 1).

O grupo oposicionista à frente deste órgão de imprensa fazia questão de esclarecer que se negava a compactuar com o silêncio tecido em torno da epidemia. De acordo com a visão dos fatos defendida pela facção 'severinista', o verdadeiro propósito de tal omissão seria o de evitar que "a Bahia viesse a aparecer, perante a nação, diminuída no seu valor, na sua dignidade, como uma terra de bugres governada por gente indigna" (id. ibid.). As autoridades baianas não desejavam se responsabilizar por um sistema sanitário em crise, nem por uma cidade "atrasada, bárbara e insalubre". Percebendo que era este o significado subjacente à questão, o redator arrematava: "Qual seria o resultado desta situação covarde? A melhor possível para o governismo" (id. ibid.).

Para acender a polêmica e manter o público leitor bem informado em meio à querela política que se estabelecia nos órgãos de imprensa vinculados às diferentes facções, eram publicadas também as intermináveis discussões travadas sobre a pandemia de gripe pela comunidade médico-científica local, nacional e internacional. As notícias sobre o assunto veiculadas pelos jornais da Bahia reve- 
13 Três correntes divergentes agitavam a comunidade médicocientífica internacional a oficial acreditava ser esta uma gripe que, tendo começado de forma benigna, agravou-se, tornandose mortal; a segunda corrente admitia $\mathrm{o}$ diagnóstico de influenza, mas estranhava as circunstâncias e sintomas anômalos que aquela epidemia vinha apresentando; por fim, a terceira corrente, que desde o princípio havia

negado o diagnóstico de influenza,

considerava tal epidemia como 'febre dos três dias',

defendendo a hipótese da existência de um agente etiológico invisível e filtrável, como o da dengue e da febre amarela, cuja transmissão se daria principalmente pela fêmea de uma espécie de mosquito - o Phlebotomus papatasi.

Vide o Diário de Notícias de $1^{\circ}$ de outubro de 1918, p. 1.

$14 \mathrm{O}$ cientista e pesquisador Antonio do Prado Valladares (13.6.1882-8.1.1938) ingressou na

Faculdade de

Medicina da Bahia contando apenas 14

anos de idade.

Concluiu o curso como aluno laureado com um prêmio de viagem de estudos à

Europa e de retrato no panteão da Faculdade. Interno da cadeira de clínica propedêutica, em pouco tempo se tornou assistente. Depois de ocupar o cargo de professor extraordinário e efetivo de patologia geral, foi transferido, em 1915, para a cátedra de clínica médica, e, em 1925, para a cátedra de clínica médica propedêutica, funções que exerceu até a morte (Souza, 1949). lavam o conflito de idéias em torno da própria identidade do agente etiológico e sua causa. ${ }^{13}$

Nesse contexto, os médicos baianos relutavam em chamar de gripe uma doença pandêmica ainda não identificada. Todos eram cautelosos em precisar a etiologia da moléstia. Entre estes se encontrava um dos mais conceituados e ilustres personagens da medicina baiana, o médico e professor Antonio do Prado Valladares. ${ }^{14}$

$\mathrm{Na}$ tentativa de esclarecer o seu público leitor acerca da epidemia de influenza, uma reportagem publicada no Diário da Bahia (3.10.1918, p. 1) informava o que Prado Valladares pensava em relação àquela enfermidade. Questionado sobre a natureza da moléstia, o médico não emitia uma opinião definitiva, mas não excluía a hipótese de tratar-se de uma moléstia mais grave do que se estava a supor; arriscou-se a dizer, mesmo tendo observado poucos doentes, que o mal em questão não tinha relação com a "febre catarral meteórica", denominada comumente de influenza. Tal conjectura considerava a "freqüência de manifestações eruptivas" nos enfermos acometidos pelo mal, muito semelhantes àquelas que apareciam em caso de 'dengue'.

Assim, suspeitava, ainda que sem muita convicção, de que a epidemia reinante na Bahia era a mesma que grassava na África e na Europa. Cauteloso, porquanto não tinha um conhecimento preciso do agente mórbido, o médico recomendava: "Eis aí um excelente ensejo de estudos, grandemente úteis e louváveis, para o ânimo pesquisador dos nossos estudiosos das coisas clínicas" (id. ibid.).

As notícias que circulavam nos periódicos de Salvador refletiam a perplexidade da população diante do grau de virulência que uma doença, até aquele momento vista como benigna e familiar, vinha apresentando. "Será gripe? Influenza espanhola? Ou simples andaço sem graves consequiências?" - questionava o articulista do Diário da Bahia $(3.10 .1918$, p. 1). De acordo com a matéria jornalística veiculada nesse periódico, a sociedade baiana estava seriamente apreensiva "em face do caráter indiscutivelmente epidêmico que estava assumindo um mal cuja mesma índole clínica até então não se conhecia". Para o jornalista do Diário, o morbo em questão diferia completamente daquele que tinha afetado a população baiana em anos anteriores (id. ibid.). Sobre o assunto, o referido jornalista assim se manifestava:

Ora, uma das evasivas a que a farândula governante se apega, (...) é precisamente a benignidade com que o mal se tem, até o momento apresentado, a ponto de estar sendo indébita e malavisadamente confundido, em sua feição epidemiológica, com o andaço simples e vulgar que os antigos denominavam peitorréia, febre catarral pan-epidêmica, cuja fisionomia clínica difere, absolutamente, da sob a qual se nos tem deparado o atual morbo, que aí está a prostrar $50 \%$ e quiçá mais da população. 
$15 \mathrm{O}$ dr. Frederico Koch era inspetor sanitário do $15^{\mathrm{o}}$ distrito e professor da Faculdade de Medicina da Bahia, ocupando a cadeira de farmacologia e arte de formular no período de 1917 a 1919; o dr. Aristides Novis lecionou na mesma instituição e, no ano de 1919, ocupou a cadeira de fisiologia; era também inspetor sanitário do $7^{0}$ distrito; o dr. Dyonisio Pereira também era inspetor sanitário do $4^{\mathrm{o}}$ distrito. Para saber mais, ver Eduardo de Sá Oliveira em Memória Histórica da Faculdade de Medicina da Bahia concernente ao ano de 1942 (Salvador, Centro Editorial e Didático da UFBA, 1992, p. 431-5).

16 A comissão visitou os quartéis e as enfermarias do Exército, da Brigada Policial, da Guarda Civil, Colégio dos Órfãos de São Joaquim e da Escola de Aprendizes de Marinheiros, entre outras instituições e espaços onde se concentrava um grande número de pessoas (Gazeta Médica da Bahia, 1918, p. 151).
E enquanto a sua repercussão sobre a vida ordinária se vai acentuando dia a dia, em perturbações de ordem altamente séria, o governo nada faz mais, até agora, além de esperar que se precise a etiologia da moléstia (Diário da Bahia, 3.10.1918, p. 1, grifos nossos).

Enquanto isso não acontecia, o mal se alastrava pela cidade. "E não há epidemia na Bahia...!", ironizava o artigo estampado na primeira página de $A$ Tarde no dia $1^{\circ}$ de outubro de 1918. Essa matéria jornalística informava os últimos números e a localização dos acometidos pela influenza:

A fábrica Stella não trabalhou hoje. A maioria dos operários adoeceu de "influenza".

(...)

$\mathrm{Na}$ Escola de Aprendizes a Marinheiros, do $1^{\mathrm{o}}$ tenente Arthur Seabra ao suboficial Biavati, caíram enfermos 35 aprendizes. Dos três cozinheiros, resta apenas de pé, um, esse mesmo sob ameaça do mal.

No $11^{\circ}$ Regimento do Exército, foram notificados cerca de 300 casos; na polícia, na guarda civil, no corpo de bombeiros, a epidemia manifestou-se também assustadoramente.

De carregadores a estivadores, a percentagem é assombrosa de enfermos. (id. ibid)

Pressionado pela imprensa, o diretor de Saúde Pública da Bahia, dr. Alberto Muylaert, nomeou uma comissão para estudar o caso. Para tal, escolheu representantes da elite médica estadual, possuidores de grande credibilidade não só entre seus pares como em toda a sociedade baiana. ${ }^{15}$ Assim, os médicos Frederico Koch, Dionysio Pereira e Aristides Novis ficaram responsáveis por apresentar um parecer, com a maior brevidade possível. A comissão, incumbida de averiguar "a natureza, difusão e gravidade da moléstia", realizou a inspeção em coletividades diversas. ${ }^{16}$

Após ter examinado um número superior a quinhentos doentes, os médicos observaram que a gripe vinha se manifestando "na sua forma comum - a respiratória, algumas vezes cortejada de ligeiros distúrbios gastrointestinais"' (Gazeta Médica da Bahia, p. 1512). "A moléstia se instala[va] rapidamente", e em geral os acometidos pela doença apresentavam "elevação térmica", numa escala "de 38 a quarenta graus, fenômenos inflamatórios para o lado das vias respiratórias superiores, mialgia, cefaléia e lassidão" (id. ibid.). Para esses médicos, sob tratamento, tais manifestações mórbidas poderiam se intensificar, mas se atenuariam e desapareceriam num prazo médio de três ou quatro dias. Os sintomas observados eram comuns a uma doença há muito fam liar aos baianos, que visitava 
17 Tal diagnóstico tinha por base o estudo do

bacteriologista alemão Richard Pfeiffer, que, a partir da análise do escarro dos gripados e da dessecação do aparelho respiratório das vítimas, conseguiu isolar, em 1892, o Haemophilus influenzae, conhecido como bacilo de Pfeiffer (Bertolli Filho, 2003).

$18 \mathrm{Na}$ oportunidade, a comissão assumiu o conhecido discurso higienista.

Considerava que as habitações coletivas eram núcleos importantes de propagação da doença. Além disso, acreditava que a influência de certas condições meteorológicas, como as oscilações bruscas de temperatura, de pressão e umidade atmosféricas, aliadas ao papel do ar na veiculação mórbida, dificultavam ou mesmo tornavam impossível o estabelecimento de medidas infalíveis de profilaxia da gripe (O Democrata, 4.10.1918).
Salvador com uma certa periodicidade. Portanto, era natural que, a priori, esses médicos julgassem estar tratando com o mesmo tipo de agente etiológico.

Assim, os médicos comissionados para estudar a epidemia concluíram que não se tratava de qualquer doença nova, apavorante pela "novidade ou pelos efeitos, mas sim de gripe ou influenza, suficientemente caracterizada na sua fisionomia clínica, gripe periodicamente observada na Bahia, com a sua costumada benignida$\mathrm{de}$ ", embora alcançasse, naquele período, um "raio mórbido muito maior" (id. ibid., p. 151).

Apesar da disseminação da gripe na capital, os médicos mencionados registraram apenas seis óbitos, dos quais dois foram atribuídos a um estado mórbido preexistente, e três à falta de assistência médica. Para a comissão, o mal não tomaria "outro caráter de virulência", tendo em vista que o clima da Bahia era "impróprio às calamitosas façanhas do diplo-bacilo de Pffeifer" (id. ibid., p. 152). ${ }^{17}$ Tal diagnóstico baseava-se nos elementos clínicos possíveis de se reunir, considerando os "limites da brevidade exigida pelo caso".

No entanto, mesmo achando que a moléstia era gripe ou influenza, doença familiar e benigna, os médicos integrantes da comissão sugeriram a adoção de algumas práticas profiláticas. A comissão acreditava que as desinfecções sistemáticas em lugares onde houvesse trânsito ou aglomeração de pessoas, a irrigação constante das ruas, bem como as medidas de higiene individuais, ainda que não jugulassem o mal, teriam certamente a virtude de restringir seu desenvolvimento (O Democrata, 4.10.1918). ${ }^{18}$

Contudo, tais medidas não foram logo executadas, e o mal não arrefecia. O raio de ação da epidemia se alargava, e a imprensa registrava a paralisação de fábricas e a diminuição do tráfego da Linha Circular. O Diário da Bahia (5.10.1918, p. 1) noticiava que "operários e trabalhadores, às centenas", eram presas da moléstia, "altamente contagiosa", e o jornalista argumentava que, por mais benigna que esta se parecesse, não deixavam de impressionar as suas conseqüências, que de forma nenhuma se assemelhavam ao de uma "simples influenza, passageira e rápida".

Nessas circunstâncias, a reportagem publicada no Diário chamava a atenção para um problema mais amplo - o da saúde pública - para o qual "ainda não lançaram suas vistas os donos da situação". De acordo com a matéria, a Bahia era uma terra em que se negligenciavam as medidas de higiene; por conseqüência, seus habitantes estavam sujeitos “às agressões dos morbus mais violentos", sem ter qualquer "meio de defesa senão a própria resistência orgânica". Assim, era justo que a população, "batida pela fome e pela miséria", e atormentada pela febre amarela, pelo impaludismo e pelo mal epidêmico reinante, se mostrasse presa de "uma série infinita de apreensões, de dúvidas e desgostos" (id. ibid., p. 1). 
Até então a Diretoria Geral de Saúde Pública da Bahia não tinha tomado as providências para debelar o mal. As matérias jornalísticas veiculadas pela imprensa revelavam a impaciência da população diante de tanta morosidade. Sobre tal estado de coisas, a argumentação de um articulista do Diário da Bahia era contundente - "influenza espanhola ou brasileira; a febre dengue, ou de papatasi, qualquer que seja o mal que nos agride, deve de ser combatido" (Diário da Bahia, 11.10.1918, p. 1). Indignado com a apatia das autoridades sanitárias diante de um morbo em processo de franca expansão, o referido jornalista questionava: por que o governo do estado não instituiu a vacina jeneriana como fora feito no Rio de Janeiro? "Por que não se estabelecem as desinfecções domiciliares?" Para o repórter, a fim de aprofundar os estudos sobre o morbo e estabelecer um meio mais eficaz de observação, o governo deveria considerar a moléstia como de notificação obrigatória. Porém, tendo em vista que até então nada tinha sido feito para obstar o mal, o articulista não poupava as autoridades de sua crítica irônica e mordaz como poderemos observar a seguir:

A própria comissão pediu uma série de medidas profiláticas.

Pô-las em prática o sr. Antonio Moniz?

Nada nos consta a respeito.

Provavelmente o sr. Gonçalo está inventando novo fogareiro para o necessário serviço de desinfecção.

Aí é que cabe toda a culpa ao situacionismo (id. ibid., p. 1)

No Diário de Notícias também foi publicada uma matéria que censurava o posicionamento das autoridades diante da ameaça da epidemia. Assumindo o discurso higienista, o jornalista argumentava que, tendo em vista que o micróbio da influenza vivia no ar, os lugares onde este já era impuro deveriam ser saneados. Assim, pontos tais como teatros, casas de espetáculo, cinemas etc., onde havia aglomeração de pessoas, muitas das quais sem obedecer aos preceitos básicos de higiene, deveriam ser fechados para evitar que o mal se propagasse. Para esse jornal, apesar de a moléstia ter se apresentado, de início, na sua forma benigna, "não era por isso que deveria merecer menos cuidado" (18.10.1918, p. 1). O articulista clamava por providências, pois a população encontrava-se aterrorizada diante do crescimento da mortandade, e mesmo porque o grau de morbidade da doença afetava as atividades produtivas, causando a "falta de energia" e de "braços em todas as repartições de trabalho".

Como se afirmou anteriormente, o desconhecimento do agente etiológico e a lentidão talvez provocada pelos trâmites burocráticos do serviço público fizeram com que as medidas profiláticas preconizadas pela comissão de médicos não fossem de pronto executa- 
das. Portanto, a 'espanhola' transitava livremente pelos becos e cortiços de Salvador.

O mês de outubro foi um dos mais difíceis daquele ano de 1918. O Livro de Registro de Enterramentos do cemitério da Santa Casa de Misericórdia, o Campo Santo, registrou 41 óbitos por gripe ou complicações decorrentes desta moléstia (ASCM-BA; H/Base/1331; 7.12.1915 a 26.8.1923). Entretanto, no mesmo período, as informações oficiais fundamentadas em notificações dos inspetores sanitários apontavam para um decréscimo sensível do índice de pessoas acometidas pela gripe. A disparidade de informações revela possivelmente as intricadas relações no âmbito do poder público, a questão socioeconômica (vinculada à necessidade de preservação de uma imagem de 'salubridade') diante da desatenção à saúde da população na República Velha baiana.

Apesar das denúncias diariamente publicadas na imprensa, o dr. Muylaert, diretor da Saúde Pública, procurava não alarmar a população, persistindo na idéia da benignidade da doença. Em carta publicada no Diário de Notícias, no dia 23 de outubro de 1918, fazia o seguinte apelo:

Bahia, 21 de outubro de 1918. - Ilmo. sr. redator do Diário de Notícias - A notícia, publicada hoje em vosso conceituado jornal, [de que] "pela cidade, a epidemia continua se alastrando pavorosamente" não está de acordo com os dados colhidos pelos inspetores sanitários por solicitação minha, em colégios, quartéis, e demais casas coletivas e informes das principais farmácias, no que se refere ao receituário, pois verifica-se o decrescimento sensível da gripe. Espero que fareis a necessária retificação, para tranqüilidade da população, com que muito obsequiareis o vosso leitor. - A Muylaert."

Em contrapartida, seja por uma manobra política ou por um compromisso ético com o público leitor, os jornais continuavam denunciando a dissonância entre os números oficiais e a pavorosa realidade da população baiana. O Diário de Notícias chamava a atenção para o seguinte aspecto da questão:

Pelas informações oficiais, isto é, pelas notificações dos inspetores sanitários, em colégios, quartéis etc., verifica-se o decrescimento sensível da gripe.

Esses funcionários, porém, não deram conta do número de doentes, que não procuram médicos nem farmacêuticos, e que se curam por meio de folhas e receitas caseiras, número este que, parece-nos, não havia decrescido até o dia em que escrevemos a afirmativa contestada.

Demais, grande parte do povo julga d'outro modo a epidemia reinante e, no caso, descrê da palavra oficial; e, assim, a existência 
19 O dr. Octavio Torres (1885-1922) foi professor da

Faculdade de Medicina da Bahia, assumiu o cargo de diretor interino do Serviço de Estatística Demográfico-Sanitária da Bahia, foi membro da Sociedade Médica dos hospitais da Bahia e da Sociedade de Medicina da Bahia. de grande número de enfermos infensos à visita médica que se lhe tornará pesada atualmente, pela carestia dos medicamentos (Diário de Notícias, 23.10.1918, p. 1, grifos nossos).

Como afirmou a comissão de médicos, a gripe era uma doença que atacava a população baiana sazonalmente. Portanto, era uma moléstia familiar, cujos sintomas - febrícula, coriza, dor de cabeça e pelo corpo - causavam incômodo, sem trazer, na maior parte dos casos, graves conseqüências. Assim, quando acometidos pela moléstia, raramente os soteropolitanos recorriam aos médicos. Cuidavam das suas mazelas com receitas caseiras passadas de geração a geração. Sob os cuidados domésticos, os sintomas desapareciam num prazo de três a quatro dias.

É possível que, de início, muitos tenham acreditado que se tratava daquela gripe costumeira, e usaram o tratamento convencional. Além do mais, não era fácil obter assistência médica na capital da Bahia. Nas primeiras décadas do século XX, as camadas mais pobres da sociedade não tinham fácil acesso aos serviços médicos, muito caros para aqueles que não podiam garantir as mínimas condições materiais de existência.

Havia em Salvador o Serviço de Assistência Pública da Bahia, inaugurado em 1916, no Governo Seabra (Torres, 1923). ${ }^{19}$ Entretanto, no Posto Central da Assistência Pública, só eram praticadas intervenções cirúrgicas (cura de hérnias estranguladas, laparotomias, suturas de órgãos, ligaduras de artérias, amputações etc.) e socorros médicos em casos urgentes de envenenamentos, tentativas de suicídios, acidentes etc. (id. ibid.). Nada consta, na descrição do dr. Octavio Torres, a respeito das instalações e do funcionamento do posto, que ali fosse prestado algum tipo de assistência ambulatorial.

Transcorrido um mês desde que Salvador se encontrava sob a ação nefasta da 'espanhola', a Diretoria Geral de Saúde Pública resolveu implementar medidas de prevenção e combate à moléstia: foram ordenadas as lavagens das ruas e das praças; a desinfecção dos mercados públicos, dos ascensores e das estações e a lavagem dos bondes, principalmente dos mortuários. Para acolher os indigentes atacados pela moléstia, foi instalada uma enfermaria especial no Hospital de Isolamento de MontSerrat. Além disso, a cidade foi dividida em seis zonas para facilitar a inspeção e a assistência médica; nomearam-se médicos comissionados para o tratamento dos indigentes atacados de gripe na capital e no interior; farmácias foram cadastradas para atender os 'espanholados'.

De acordo com os registros do Serviço de Estatística DemografoSanitária, o serviço especial de assistência médica e farmacêutica aos indigentes atacados de gripe atendeu 216 pessoas no período relativo a 27 de setembro a 31 de outubro (O Democrata, 10.11.1918). 
20 De acordo com Luís Henrique Dias Tavares, entre 1910 e 1920, além das firmas dedicadas ao comércio exportador, havia em Salvador um largo e heterogêneo espectro de "fábricas, fabriquetas e oficinas".

Entretanto, o autor afirma que "a indústria baiana era formada principalmente por fábricas de tecidos e usinas de açúcar" (Tavares, 2001, p. 365). Recorrendo a um critério baseado no tamanho e qualidade das instalações, bem como no número de operários empregados nestas atividades, Tavares relaciona 36 estabelecimentos dedicados às atividades fabris na Bahia. Entre eles, o autor destaca as fábricas de tecidos pertencentes à Companhia Progresso Industrial da Bahia, a

União Fabril e Empório Industrial do Norte, Companhia Valença Industrial (cuja fábrica estava sediada em Valença), compostas por um total de nove unidades produtivas que empregavam 1.625 operários. Além destas, o autor listou 12 usinas de açúcar, quatro fábricas de cigarros, seis de "calçados, alpercatas e chinelos", e as fábricas de charutos, das quais o autor considerou importante registrar apenas seis unidades (id. ibid., p. 36)
As informações recolhidas por esse órgão diziam respeito aos distritos de Salvador; não foram computados os casos ocorridos na zona suburbana. Esses dados eram relativos a enfermos sem recursos financeiros, que lançavam mão do serviço público e gratuito. Conforme um aviso publicado na imprensa local, a assistência pública e gratuita só era oferecida às pessoas reconhecidamente indigentes, e, entre estas, somente às atacadas de gripe (O Democrata, 25.10.1918, p. 1). Assim, o estado garantia a assistência daqueles que não poderiam prover o seu próprio bem-estar, por não possuir uma atividade remunerada definida.

No período de 25 a 26 de outubro de 1918, foram visitados pela Inspetoria de Saúde 34 estabelecimentos, abrangendo indústrias e fábricas, bem como as companhias de transportes urbanos, gás e eletricidade, trapiches, docas etc. Segundo os registros do Serviço de Estatística Demografo-Sanitária, num espectro de 34 estabelecimentos diversos, foram inspecionados 5.812 trabalhadores, dos quais $52,9 \%$ contraíram a moléstia (O Democrata, 6.11.1918). ${ }^{20}$

Analisando os dados da estatística oficial, percebemos que, em algumas unidades produtivas, o trabalho foi completamente paralisado, tendo em vista que, senão todos, pelo menos a maioria dos trabalhadores havia sido acometida pela moléstia cujos sintomas levavam três, quatro ou mais dias para desaparecerem, quando não resultava em óbito.

Nem sempre o serviço da Inspetoria de Saúde era levado a termo de forma satisfatória. Nos populosos distritos fabris, o elevado número de moradores concentrados em becos, vilas e avenidas, e o "penosíssimo deslocamento" até estes locais dificultavam ou mesmo impediam a ação sanitária dos inspetores (Figueiredo, DGSP, Inspetoria do 9o distrito, Bahia, 1913). Portanto, muitos eram os que morriam sem que o serviço público tomasse conhecimento ou mesmo lhes prestasse algum tipo de assistência. Vejamos a notícia que se segue:

Também de gripe, faleceram, ontem, no Hospital Santa Isabel, Mônica da Silva, de 25 anos de idade, solteira, residente na rua do Paraíso e, na porta desse estabelecimento, à chuva e ao sol, em miserável abandono, morreu vítima da gripe, uma infeliz preta, de 32 anos presumíveis (Diário de Notícias, 24.10.1918, p. 1).

Notas como esta, publicadas pela imprensa, nos levam a crer que apenas as pessoas identificadas e integradas de alguma forma àquela sociedade - com nome, idade e endereço conhecidos - obtinham algum tipo de atendimento de saúde. Os anônimos, aqueles que viviam na mais absoluta miséria, à margem da sociedade, morriam ao relento e certamente não eram computados pela estatística oficial.

Todavia, diante da marcha desenfreada do morbo, alguns setores da sociedade também se mobilizaram no sentido de combater 
ou minimizar os efeitos da epidemia. A Congregação da Faculdade de Medicina da Bahia aprovou a proposta apresentada pelo professor de higiene, dr. Josino Cotias, que ofereceu ao governo do estado os seus serviços, tendo em vista o momento "de crise pavorosa, determinada pela presença (...) da influenza", que vinha se alastrando rapidamente, fazendo "várias vítimas" (Diário de Notícias, 25.10.1918, p. 1).

O Mosteiro de São Bento, ciente dos "sérios embaraços" que o diretor de Saúde Pública estava enfrentando para acomodar os doentes atacados pela gripe, desempenhou um papel importante na articulação de medidas para enfrentamento da epidemia. Em carta enviada ao diretor-geral de Saúde, em 28 de outubro de 1918, o abade do Mosteiro de São Bento, d. Rupperto Remdolf, ofereceu ao governador as instalações do Mosteirinho de Mont Serrat, que servia como sanatório aos religiosos, para abrigar os 'espanholados' (APEBA, Seção republicana, Cartas Recebidas pelo diretor-geral de Saúde..., 1917-18).

Quando os homens que trabalhavam na reconstrução do ramal centro-oeste da rede ferroviária da Bahia foram acometidos pela gripe, os responsáveis pelo Serviço Médico da Compagnie Chemins de Fer Federaux de L'Est Brésilien informaram à Diretoria Geral de Saúde que haviam sido prestados os necessários cuidados aos doentes, muitos atacados também de impaludismo, fazendo-se ainda a retirada, para desinfecção, dos carros existentes em Água Comprida, e onde se recolhiam os referidos trabalhadores (O Democrata, 27.10.1918, p. 1-2).

Sensibilizado com o estado de miséria dos muitos enfermos que o requisitavam, o dr. Democrito Calazans também ofereceu os seus serviços médicos ao governo, prontificando-se a atender aos indigentes que o procurassem na sua residência. Para tanto, solicitava ao diretor de Saúde Pública que designasse uma farmácia no seu distrito "onde fossem aviadas as receitas", visto que "o estado de miséria" daqueles que buscavam a sua assistência não permitia a "aquisição de remédios", naquela época, "de custo assaz elevados" (Diário da Bahia, 1.11.1918, p. 1). Esse documento demonstra também que muitos enfermos, mesmo os mais pobres, iam diretamente à casa do médico, dificultando a contabilidade dos atingidos pela epidemia pelo Serviço de Estatística Demografo-Sanitária.

Assim, não se pode descartar a hipótese de que a Diretoria Geral da Saúde Pública da Bahia desconhecesse o número real de pessoas acometidas pela influenza maligna. Tendo em vista que esta não era uma doença de notificação obrigatória, é possível que não fossem registrados os doentes que recorriam ao médico de família ou se dirigiam àquele que morava próximo às suas residências.

Por outro lado, não podemos deixar de considerar a resistência que algumas pessoas apresentavam em relação à medicina acadê- 
mica, ainda mais quando, a princípio, se acreditava tratar-se de uma doença benigna, comumente curada com repouso e mezinhas caseiras. Além disso, não podemos esquecer que aquele era um momento em que a carestia imperava, e a pobreza recrudescia. Portanto, é provável que muitas das vítimas da influenza não tivessem recursos para procurarem um médico, tampouco para aviarem suas receitas em farmácias.

Considerando-se igualmente que nem sempre o serviço da Inspetoria de Saúde era realizado a contento, muitas pessoas deviam escapar à inspeção, sem falar naquelas que, embrutecidas pela miséria, não recorriam nem recebiam nenhum tipo de assistência, morrendo à míngua. Não obstante, o Serviço de Estatística Demografo-Sanitária computou 216 óbitos por influenza entre 27 de setembro e 31 de outubro de 1918 (O Democrata, 10.11.1918, p. 2).

O Serviço de Verificação de Óbitos tinha o cuidado de registrar as características gerais das vítimas, informando ao Serviço de Estatística Demografo-Sanitária dados como nacionalidade, estado civil, cor, idade, profissão e endereço. Essas informações nos permitem traçar um perfil dos vitimados pela doença. Tomando como base estes elementos, inferimos que a maioria dos óbitos ocorreu entre os trabalhadores e aqueles grupos denominados pelo serviço público como indigentes; pessoas cujos organismos já debilitados por outras doenças crônicas ou carenciais ou por condições de sobrevivência subumanas não poderiam oferecer resistência à invasão daquele inimigo invisível. Este perfil correspondia às condições gerais de grande parte da população baiana no ano de 1918 - acossada pela carestia, abatida pela fome, desalojada pelas reformas urbanas (aglomerada em lugares mal arejados, úmidos e escuros) e alquebrada por epidemias precedentes. Observemos o gráfico abaixo e vejamos, a seguir, como esta proposição se justifica:

Como se pode verificar no gráfico, a maior parte dos óbitos registrados pelo Serviço de Verificação de Óbitos ocorreu no distri-

Gráfico I

Mortalidade gripal por distrito no período de 27.9 a 31.10.1918

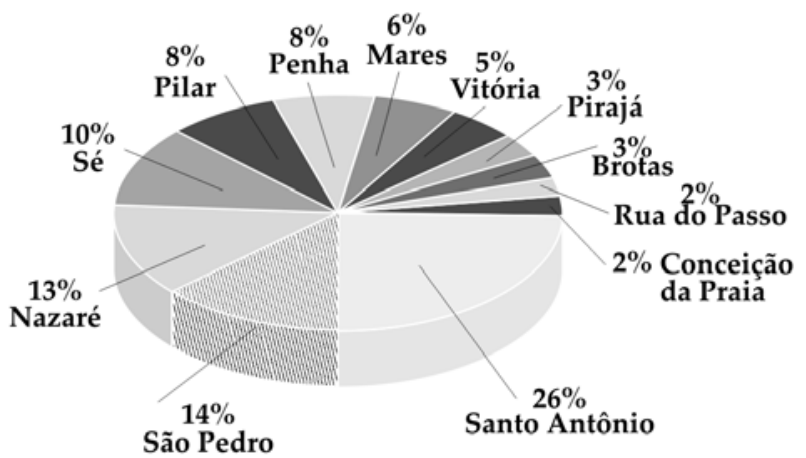

Fonte: O Democrata, 10.11.1918, p. 1. 
21 O $2^{\circ}$ distrito, Santo Antônio Além do Carmo, compreendia o que hoje são os bairros da Liberdade, Fazenda Grande e São Caetano (Cardoso, 1991).

22 Grupo de casas geminadas, alinhadas em ruas preexistentes. to de Santo Antônio Além do Carmo. ${ }^{21}$ De a cordo com Cardoso (1991), esta era uma área ocupada pelos segmentos mais empobrecidos da população - além dos operários fabris, dos empregados dos estabelecimentos comerciais e das companhias dos serviços urbanos, aí se fixavam preferencialmente os que viviam do mercado informal de trabalho.

O distrito de Brotas, que aparece nas estatísticas com uma concentração significativa de óbitos, abrigava parte da população fabril. Ainda segundo Cardoso, neste distrito, principalmente nas imediações da atual rua Djalma Dutra, estavam situadas unidades habitacionais 'proletárias' e uma vila operária da fábrica de tecidos São Salvador.

Em Nazaré, distrito que abrigou o terceiro maior número de vítimas, estava situado o Hospital da Santa Casa de Misericórdia, o Santa Isabel, para onde eram levadas as pessoas acometidas pela doença (O Democrata, 10.11.1918, p. 2). Esse distrito apresentava uma feição heterogênea, pela sua ocupação por parte da camada pobre e média daquela sociedade (Pinheiro, 2002). Além disso, Nazaré ficava próximo ao centro administrativo e comercial da cidade, portanto, aí deveriam morar as pessoas que necessitavam estar próximas ao local de trabalho.

Nos distritos centrais da Sé, Pilar, São Pedro, Conceição da Praia e rua do Passo, as famílias se amontoavam em 'avenidas' ${ }^{22}$ ou em sobrados subdivididos, na esperança de aí encontrarem uma oportunidade de trabalho. A Penha e os Mares eram distritos onde estavam localizadas as principais indústrias de Salvador, e aí se concentravam também os seus operários (id. ibid.). No que se refere à Vitória, os pobres se fixaram nas áreas dos atuais bairros do Garcia, Fazenda Garcia, Federação e imediações do Porto da Barra, área originalmente ocupada por pescadores (id. ibid.).

Segundo a estatística oficial, até 30 de novembro de 1918, a influenza maligna teria infectado cerca de 130 mil pessoas entre os 320 mil habitantes de Salvador. Ou seja, num período de 65 dias, $40,6 \%$ da população haviam contraído a doença (Aragão, 1919). Considerando-se o mesmo intervalo de tempo, estimava-se que 338 pessoas tinham sido vitimadas pela gripe, numa média diária de 5,2 óbitos provocados por esta moléstia (id. ibid.).

Em finais de novembro de 1918, a 'espanhola' resolveu dar uma trégua aos soteropolitanos, e o número de casos começou a decrescer. O governador se apressou em enviar um telegrama comunicando o declínio da epidemia ao presidente da República, do qual recebeu a seguinte resposta:

Rio, 10 - Dr. Antonio Moniz, governador Bahia. - Recebi com muito prazer o telegrama de V.Ex ${ }^{\underline{a}}$, noticiando estar quase extin- 
ta a epidemia nessa capital, pelo que apresento a V. Ex ${ }^{\underline{a}}$ minhas felicitações - Wenceslau Braz (Diário de Notícias, 12.11.1918, p. 2):

Findo o período de crise sob o domínio do flagelo, as autoridades baianas se regozijavam por acreditarem que a 'espanhola' havia sido mais complacente com os baianos do que com os demais habitantes do país. Para o governador da Bahia, aquele foi um evento mundial, e, na visão da autoridade baiana, o mal que a gripe espanhola causara na Bahia foi menor que em outros estados, a exemplo do Rio de Janeiro (Aragão, 1920, p. 51-5). Para Antonio Moniz, em Salvador, "pequenos foram, relativamente, os transtornos acarretados pela epidemia" (id. ibid., p. 85). Segundo o governador, a Bahia foi "um dos lugares do mundo em que a epidemia de influenza foi mais benigna, menos mortífera e menos extensa" (Aragão, 1919, p. 51).

Vale acrescentar que, na Bahia de Todos os Santos, durante o período do surto epidêmico, várias missas foram rezadas, rogando a proteção divina para aquele período de pestilência e mortalidade. É possível que Deus tenha atendido às preces dos soteropolitanos e se compadecido das condições adversas em que estes viviam debilitados por epidemias precedentes, açoitados pela carestia, combalidos pela fome e vivendo amontoados em lugares insalubres -, resolvendo poupá-los de mais essa desventura.

\section{Considerações finais}

A narrativa sobre a gripe espanhola em Salvador pode apresentar alguma similitude com outras histórias sobre a epidemia nas diferentes cidades em que o fato ocorreu. Há uma espécie de dramaturgia comum às epidemias, que, de modo geral, apresentam dilemas semelhantes, nascidos da necessidade de explicá-las e combatê-las, e as respostas se vão se repetindo ao longo da história (Slack, 1992). Não obstante, é preciso considerar a complexidade das negociações acerca da definição e da resposta à doença, que envolve atores e ações diversas, em contextos, por vezes, multidimensionais.

Em Salvador, assim como em outras cidades do Brasil, quando os primeiros rumores da existência de uma epidemia de gripe começaram a circular, as autoridades não tomaram logo providências tratava-se apenas de uma enfermidade familiar à sociedade baiana, que, até então, vinha se apresentando na sua forma benigna.

A crença de que se tratava do surto de uma doença benigna, familiar, talvez possa ter interferido na resposta inicial que aquela sociedade deu à epidemia, contribuindo para que, de início, ela fosse ignorada. Isso pode ter ocorrido tanto porque sua presença sazonal entre os soteropolitanos fizesse com que esta fosse menos extraordi- 
nária e surpreendente, como também porque o contexto político e socioeconômico não permitia que ela se tornasse de imediato um assunto público e político. Além disso, a dificuldade em se estabelecer o agente etiológico também pode ter contribuído para desnortear as autoridades sanitárias e postergar a tomada de decisões.

Por outro lado, o imobilismo das autoridades baianas diante da comprovada virulência daquele morbo evidencia as intrincadas relações no âmbito do poder público, relacionando-se à necessidade de preservação de uma imagem de 'salubridade' daquele porto agroexportador e à falta de recursos técnicos e financeiros para implementar as ações de saúde coletiva.

Quando a 'espanhola' irrompeu em Salvador, a imagem da cidade moderna, fluida, higiênica, civilizada, construída por Seabra por meio da política de ordenação do espaço urbano, não condizia com a realidade. A capital da Bahia ainda era uma cidade que convivia com condições de saneamento precárias, com carência de serviços de água, esgoto, transporte e com altas taxas de mortalidade provocadas por males epidêmicos e endêmicos. Os surtos epidêmicos eram incompatíveis com a economia agroexportadora e com a imagem idealizada de cidade moderna, higiênica, civilizada. Além disso, as epidemias eram comumente utilizadas pela oposição para obter uma intervenção federal, desacreditando, assim, os representantes da facção política que se encontrava no poder.

Na Bahia da República Velha, apesar da liderança do Partido Republicano Democrata fundado por J. J. Seabra, não havia coesão política entre as oligarquias baianas. Partidários do antigo PRB, que congregava os representantes da burguesia agrocomercial, continuavam a empreender uma oposição ferrenha à nova geração de políticos que integrava o grupo 'seabrista', que exercia o poder local.

A epidemia de gripe tornou-se então um instrumento dos diversos grupos que disputavam o controle político do estado. Assim, no período de incidência da gripe espanhola, os governistas procuravam não alarmar a população, passando uma imagem de tranqüila competência na escolha e gestão das ações de saúde coletiva. Enquanto isso, a oposição procurava desconstruir tal imagem, denunciando a crise financeira do estado, o nepotismo que conspurcava todas as instâncias da administração pública e as fragilidades do serviço de saúde pública.

A idéia de relativa benignidade da manifestação da influenza na Bahia perpassou todo o transcurso da epidemia. Não obstante, ainda que o discurso oficial reforçasse o caráter relativamente brando que a epidemia assumiu em Salvador, foram tomadas todas as medidas possíveis para conter o mal. Como foi exposto no texto, ainda que não se acreditasse em medidas infalíveis para a profilaxia da gripe, foram implementadas ações de caráter coletivo, recomendando- 
23 Segundo Moniz de Aragão, "na capital de S. Paulo, cuja população era calculada em 470.872 habitantes, de outubro a dezembro, foram registrados 5.328 óbitos causados pela gripe. (...) Em Santos, com 96.050

habitantes, faleceram (...) 847 pessoas. Só no mês de outubro em que se manifestou a epidemia de influenza, foram, no Recife, cuja população é de 218.255 habitantes, registrados 1.251

óbitos com o diagnóstico de gripe. $\mathrm{Na}$ cidade de Porto Alegre, a epidemia de influenza, que lavrou de princípio de novembro a meado de dezembro, ocasionou, em todo o município da capital, que tem 140 mil habitantes, 1.316 óbitos. Elevou-se a 12.720 o numero de óbitos atribuídos à influenza, na Capital Federal, de outubro a dezembro. Naquela capital, com a população somente três vezes superior à nossa, a mortandade produzida pela gripe foi maior do que a verifi-cada nesta cidade" (Aragão, 1920, p. 85). O governador acreditava que os pequenos transtornos acarretados pela epidemia em Salvador se devia às prontas medidas profiláticas tomadas pela Diretoria Geral da Saúde da Bahia (id. ibid.). se também que fossem adotados alguns cuidados individuais.

O discurso construído acerca da 'democracia da doença' foi importante para mobilizar os diferentes segmentos da sociedade. Porém, ainda que atingisse a todos de forma indiferenciada, a maioria das vítimas era constituída por trabalhadores e por aqueles grupos denominados pelo serviço público como indigentes. Isso se justifica quando observamos, qualidade de vida de grande parte da população baiana no ano de 1918 - desalojada pelas reformas urbanas, aglomerada em lugares insalubres e alquebrada pela carestia, pela fome e por epidemias precedentes. Nessas condições, é compreensível que os organismos já debilitados por outras doenças crônicas ou carenciais não oferecessem resistência à doença.

Era grande o número de trabalhadores infectados pela moléstia. No curto espaço de dois dias, cerca de 52,9\% dos 5.812 trabalhadores inspecionados pelo serviço público haviam contraído a gripe. A situação afetou negativamente algumas atividades produtivas, tendo em vista que a doença, quando não resultava em óbito, deixava as pessoas sem condições de trabalho por pelo menos três a quatro dias. Assim, a paralisação da produção em fábricas e em serviços diversos, em decorrência da epidemia, contribuiu para agravar a situação de uma economia já combalida, dependente do capital estrangeiro e afetada pelos transtornos causados pela guerra (que dificultava a circulação de mercadorias e de passageiros).

Depois de passada a crise, o governador Moniz de Aragão fez questão de afirmar que a Bahia foi "um dos lugares do mundo em que a epidemia de influenza foi mais benigna, menos mortífera e menos extensa" (Aragão, 1919, p. 51). Sobretudo porque, numa população de 320 mil habitantes, estimava-se que cerca de $130 \mathrm{mil}$ contraíram a gripe e apenas 386 pessoas morreram em decorrência da moléstia (Aragão, 1920). ${ }^{23}$ Era importante ressaltar esse fato, pois a Bahia era vista no resto do país como um porto 'sujo', disseminador de doenças pestilenciais.

Não foi nosso propósito medir a intensidade da epidemia na Bahia, nem mesmo compará-la ao episódio da gripe em outras cidades brasileiras. A gripe é um fenômeno biológico, que tanto pode matar em uma cidade com níveis altíssimos de saneamento e com ações de saúde pública conseqüentes, como em outra, sem saneamento e com políticas de saúde ineficazes. Entretanto, a irrupção da epidemia de gripe espanhola, além de complicar o já precário quadro sanitário da capital baiana, expôs "as chagas miseráveis da Bahia" (Diário da Bahia, 6.10.1918, p. 1): a situação de pobreza da maior parte da população; a política oligárquica que gerava o clientelismo, a ingerência nas repartições públicas e as disputas de poder entre as diversas facções políticas; bem como a falta de recursos financeiros do estado e do município, que inviabilizavam a implementação de políticas públicas de saúde. 


\section{REFERÊNCIAS BIBLIOGRÁFICAS}

Abrão, Janete Silveira 1998

Bahia. Secretaria da Fazenda. Escola de Administração Fazendária 1985

Benchimol, Jaime L. 1992

Bertolli Filho, Cláudio 2003

Bertucci, Liane Maria 2004

Brito, Nara Azevedo de mar.-jun. 1997

Cardoso, Luiz Antonio F. 1991

Castro Santos, Luiz A. e Faria, Lina Rodrigues de 2003

Castro Santos, Luiz A. de 1998

Crosby, Alfred W. 1989

Ferreira Filho,

Alberto Heráclito 1993

Ferreira,

Renata Brauner 2001

Goulart, Adriana

da Costa

2003

Hochman, Gilberto 1998

Hochman, Gilberto e Lima, Nízia T. 1998

Leite, Rinaldo

César Nascimento 1996

Oliveira, Eduardo de Sá 1992
Banalização da morte na cidade calada: a hespanhola em Porto Alegre, 1918. Porto Alegre, EDIPUCRS.

A fazenda da Bahia em perspectiva histórica. Salvador, EAF.

Pereira Passos, um Haussmann tropical: a renovação urbana do Rio de Janeiro no início do século XX. Rio de Janeiro, Secretaria Municipal de Cultura, Turismo e Esportes, Departamento Geral de Documentação e Informação Cultural, Divisão de Editoração.

A gripe espanhola em São Paulo, 1918: epidemia e sociedade. São Paulo, Paz e Terra.

Influenza, a medicina enferma: ciência e práticas de cura na época da gripe espanhola em São Paulo. Campinas, Unicamp.

La dansarina: a gripe espanhola e o cotidiano na cidade do

Rio de Janeiro. História, Ciências, Saúde - Manguinhos, v. 4, n. 1, p. 11-30.

Entre vilas e avenidas: habitação proletária em Salvador, na Primeira República. Dissertação de mestrado, Salvador, Ufba.

A reforma sanitária no Brasil: ecos da Primeira República.

Bragança Paulista, Edusf.

As origens da reforma sanitária e da modernização conservadora na Bahia durante a Primeira República. Dados, v. 41, n. 3. [citado 27 setembro 2004] Disponível na World Wide Web: <http://www.scielo.br/ scielo.php?script=sci_arttext\&pid=S0011 52581998000300004\& lng=pt\&nrm=iso $>$.ISSN 0011-5258.

America's forgotten pandemic: the influenza of 1918.

Cambridge, Cambridge University Press.

Salvador das mulheres: condição feminina e cotidiano popular na belle époque imperfeita. Dissertação de mestrado, Salvador, Ufba.

Epidemia e drama: a gripe espanhola em Pelotas - 1918.

Rio Grande, Fundação Universidade Federal do Rio Grande.

Um cenário mefistofélico: a gripe espanhola no Rio de Janeiro.

Dissertação de mestrado, Niterói, UFF.

A era do saneamento: as bases da politica da saúde pública no Brasil.

São Paulo, Hucitec/Anpocs.

Condenado pela raça, absolvido pela medicina: o Brasil redescoberto pelo movimento sanitarista da primeira república. In Maio, Marcos C. e Santos, R. Ventura (orgs.). Raça, ciência e sociedade. Rio de Janeiro, Fiocruz/CCBB.

E a Bahia civiliza-se... Ideais de civilização e cenas de anticivilidade em um contexto de modernização urbana. Salvador, 1912-1916.

Dissertação de mestrado, Salvador, Ufba.

Memória histórica da Faculdade de Medicina da Bahia, concernente ao ano de 1942. Salvador, Centro Editorial e Didático da Ufba. 


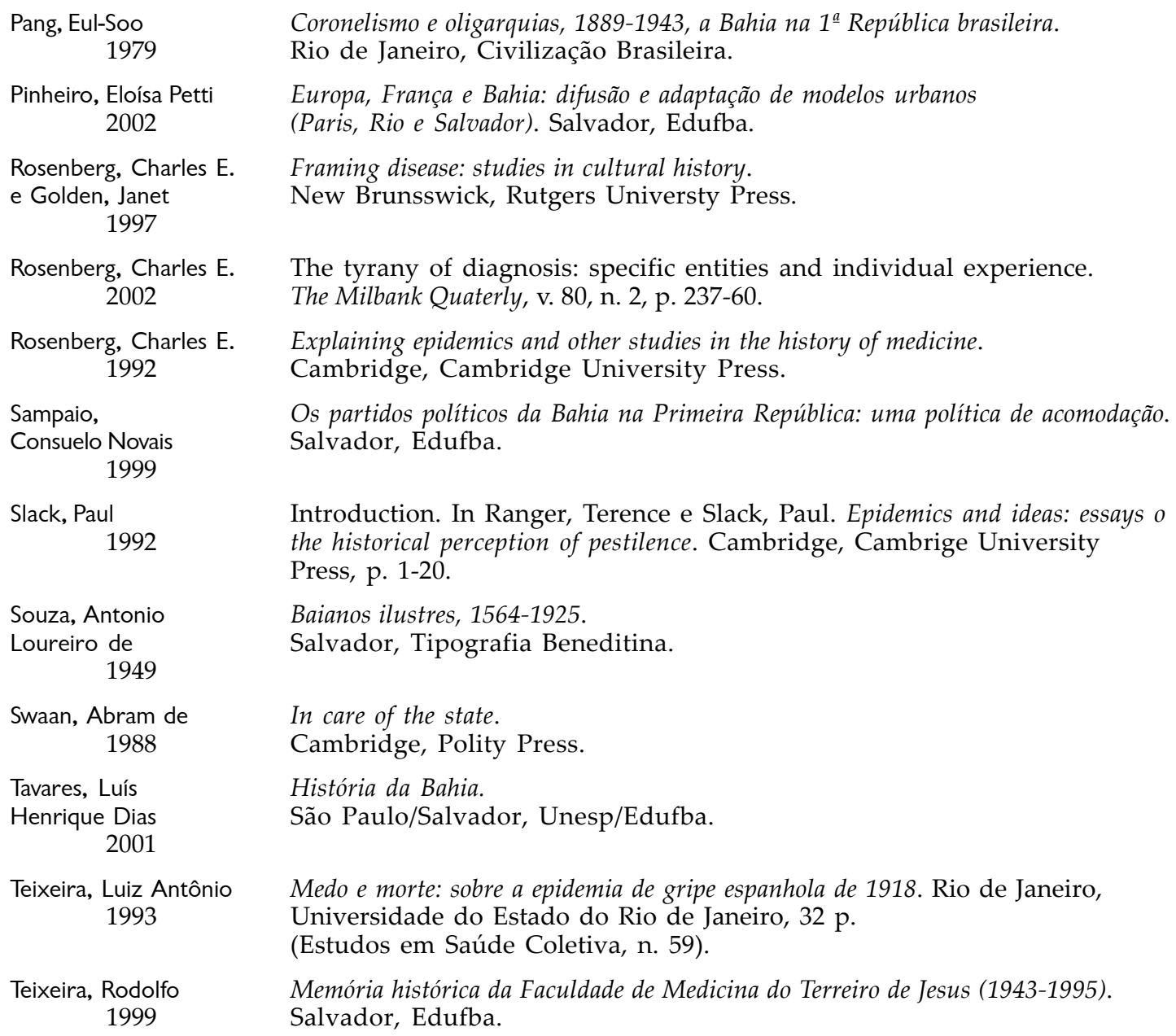

\section{FONTES PRIMÁRIAS}

PERIÓDICOS

Gazeta Médica da Bahia, vol. L, n. 4, out. 1918

A Tarde, jan.-dez. 1918-1920

Diário da Bahia, jan.-dez. 1918-1920

Diário de Notícias, jan-dez. 1918-1920

O Democrata, jan.-dez. 1918-1920

DOCUMENTAÇÃO ADMINISTRATIVA OFICIAL

Aragão, Antônio

Ferrão Moniz de 1920
Exposição apresentada pelo dr. Antônio Ferrão Moniz de Aragão ao passar o governo da Bahia ao seu sucessor, o exmo. sr. dr J. J. Seabra empossado nesse dia no cargo de governador do estado no quatriênio de 1920 a 1924. Bahia. 
Aragão, Antônio

Ferrão Moniz de 1919

Aragão, Antônio

Ferrão Moniz de 1918

Seabra, José Joaquim 1918

Secretaria do Interior e Justiça/Diretoria

Geral de Saúde 1912-1924

Secretaria do Interior e Justiça/Diretoria Geral de Saúde 1917-1918

Secretaria do Interior e Justiça/Diretoria

Geral de Saúde 1912-1918

Secretaria do Interior e Justiça/Diretoria

Geral de Saúde s. d.
Mensagem apresentada à Assembléia Geral Legislativa do Estado da Bahia na abertura da $1^{\underline{a}}$ sessão ordinária da $1^{\underline{a}}$ legislatura. Bahia.

Mensagem apresentada à Assembléia Geral Legislativa do Estado da Bahia na abertura da $2^{\underline{a}}$ sessão ordinária da $14^{\underline{a}}$ legislatura. Bahia.

Discurso pronunciado na sessão de $1^{\mathrm{o}}$ de junho de 1918 , pelo Senador Dr. José Joaquim Seabra. Pela Bahia. Defesa do seu nome, honra e crédito. Discursos proferidos no Senado da República pelo dr. José Joaquim Seabra e na Câmara dos Deputados Federais pelos drs. Arlindo Fragoso, Moniz Sodré e Raul Alves. Bahia, Imprensa Oficial do Estado.

Seção Republicana, maço 3696/1028,

Relatórios de 18 Distritos Sanitários.

Seção Republicana, maço 3688/984, Cartas Recebidas pelo diretor-geral de Saúde sobre: combate ao mosquito, peste bubônica, gripes e outros.

Seção Republicana, maço 3697/1032, Cartas Recebidas pelo diretor do Serviço Sanitário sobre Ataques de Gripe e Outros Assuntos.

Seção Republicana, maço 3696/1029, Relatórios sobre Tratamento de Indigentes atacados de gripes e febres nos municípios de Catu, Barracão e Cajueiro.

\section{DOCUMENTAÇÃO DE INSTITUIÇÕES NÃO-GOVERNAMENTAIS}

Santa Casa de

Livro de Registro de Enterramentos do Campo Santo, 7.12.1915 a

Misericórdia da Bahia

26.8.1923 - H/Base/1331.

1925-1923

\section{TESES, ARTIGOS E DISCURSOS PUBLICADOS}

Aragão, Antônio

Ferrão Moniz de 1923

Aragão, Antônio

Ferrão Moniz de 1916

Torres, Octavio 1923
Discurso pronunciado na sessão solene de abertura do Quinto Congresso Brasileiro de Geografia em 7 de setembro de 1916. Salvador, Imprensa Oficial do Estado.

A Bahia e os seus governadores na República.

Salvador, Imprensa Oficial do Estado.

Serviço de Assistência Pública do Estado da Bahia.

Salvador, Imprensa Oficial do Estado. 